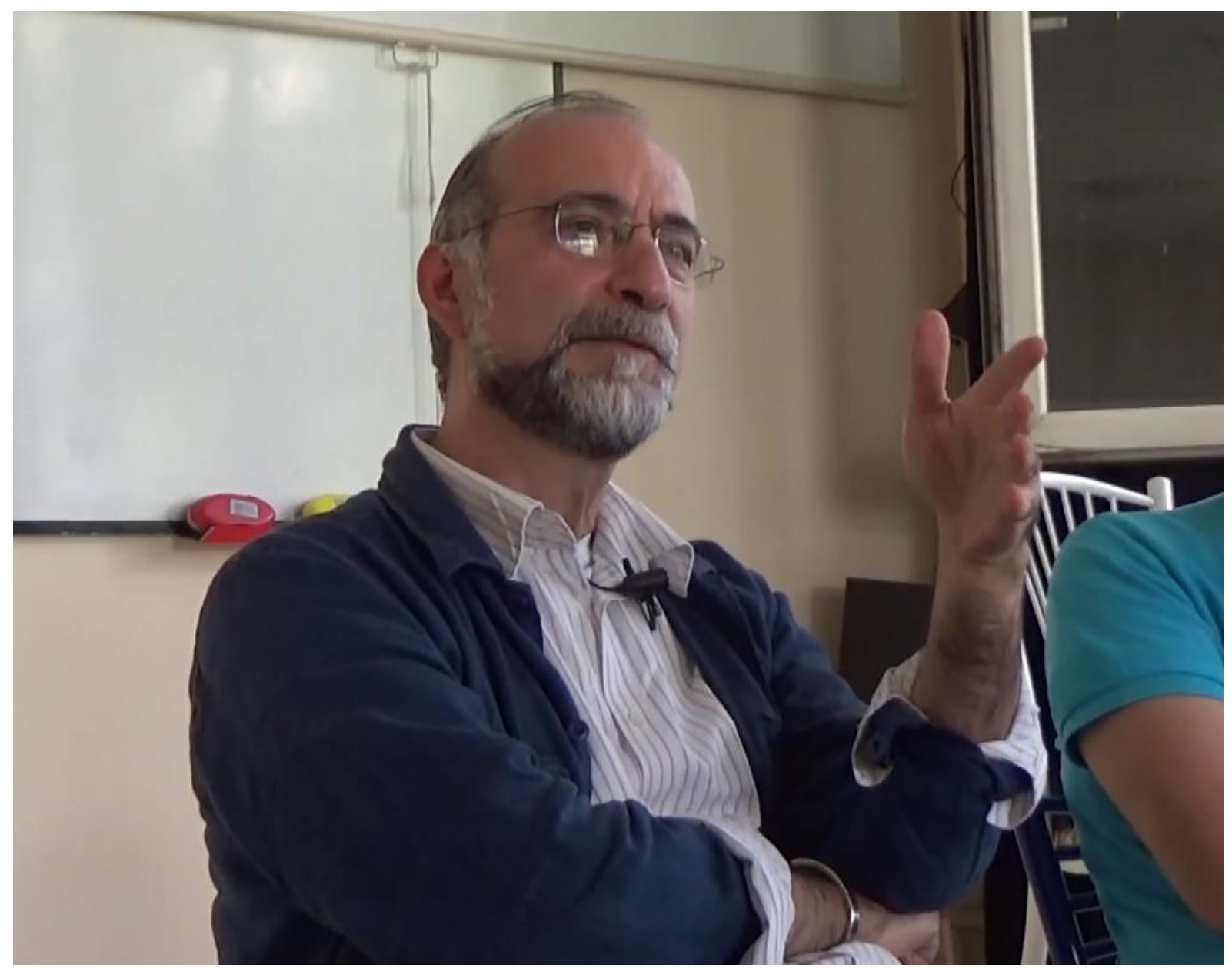

\title{
Yol Kenarı Filmi Üzerine Yönetmen Tayfun Pirselimoğlu ile Söyleşi*
}

Serdar Öztürk: Hoş geldiniz. Tayfun Pirselimoğlu'nun Yol Kenarı filmi üzerine bugün tartışma, konuşma yapacağız. Muhtemelen klasik söyleşi formatımızın dışında olacak. Yani bir yöntem önerisi, film hakkında ne düşünüyorsak, film hakkında ne yorumluyorsak, Tayfun beyin de yorumlarını dinleyelim diyoruz. Yani biz bir yorum yapalım, belki merak ettiğimiz hususları Tayfun Bey'e soralım meraklı bir şekilde, Tayfun Bey de kendi dünyasını kendi evrenini bize anlatsın. Biz kendi evrenimizi anlatalım, Tayfun bey de kendi evrenini anlatsın ve böylece evrenler arasında bir karşılaşma olsun. Bu karşılaşma uyumlu olmasın, çatışmalı da olsun, önemli değil. Önemli olan sinema imajları üzerine gerçekten bir kritik yapalım, gerçekten bir tartışma yapalım diye düşünmekteyim. Yol kenarı filmi halen gösterimde. Biz sinema salonlarında filmi izledik. Şimdi ilk soracağım soru şu olacak; yani ben bu filmi izledikten sonra, bir kıyamet nasıl anlatılır? Bir kıyamet, Hollywood filmlerinde olduğu gibi hareket imajla bize anlatılabilir. Kıyamet gelmektedir, kıyameti önlemek için uğraşırsınız.

\footnotetext{
* Bu söyleşi 9 Haziran 2018 tarihinde SineFilozofi dergisinin bir etkinliği olarak gerçekleştirilmiştir. Söyleşiyi aşağıdaki bağlantı üzerinden izleyebilirsiniz:

https://www.youtube.com/watch?time_continue=2174\&v=HdqpNM_6DzE
} 
Devlet yetkilileri, politikacılar, askerler devreye girer ve biz hareketin içerisinde hareket ederiz ve film bittikten sonrada hiç bir şey kalmaz. Film bizi katarsise eriştirir, ondan sonrada hiç bir şey hatırlamayız. Fakat biz SineFilozofi toplantıları ekseninde bir filmi tartışmıştık, belki hatırlarsınız; Last Night'dı. Bu Kanada yapımı bir filmdi. Bu biraz farklı bir kıyametti, kıyameti coşkuyla karşılayan insanlar. Bu farklı bir kıyamet filmi, bir de Lars Von Trier'in Melancholia var biliyorsunuz. Melancholia da farklı biraz, biraz farklı bir kıyamet filmi. Tayfun Pirselimoğlu'nun filmi ise, bambaşka farklı bir kıyamet filmi. Yani bunların içerisinde müstesna bir yere sahip bana göre. Niye kıyamet? Bunun üzerine belki konuşmak gerekiyor. Bir, zaten film başladıktan sonra kıyamet borusu çalıyor ve bu kıyamet borusu çaldıktan sonra filmin sonuna kadar boru sesi halen devam ediyor. Yani bir ses evreni yaratmıs Tayfun Pirselimoğlu, bu ses evreni dairesel bir çevrim gerçekleştiriyor ve bu evren imajları, karakterleri, kendi içerisinde ne yapıyor, kendi içerisine alıyor, yani kristal bir evren kuruyor, sesin kendisi. Biraz önce kendisiyle de yemekte konuştuk ama bu sesin yanı sıra başka bir ses daha var yani geminin içerisinden gelen bir ses var. İlginç bir kıyamet ile karşı karşıyayız, gemi içerisinde akordeon sesleri ile karşılaşmaktayız. Bir tarafta akordeon sesi, öbür tarafta kıyamet borusu. Şimdi yani ben burada, bu sesleri işittiğimde, Deleuze'ün iki kavramı aklıma geldi. O da nedir? Dörtnal ve nakarat. Kendisine de biraz önce bunu söyledim. Ne demek bu; dörtnal ölüme doğru gider, kıyamete doğru gider depremlere, felaketler doğru gider. Dörtnal, dörtnala doğru hareket edersiniz ve bunu da ses sağlar. Yani sinemada, Deleuze'ün “Cinema 2" kitabında söylediği şeylerden birisi; ses. Fakat akordeon sesi orda tam tersine sanki durdurmaya çalışıyor. Yani dünyanın ölümsüzlüğünü durdurmaya çalışıyor, ikisi arasında sanki bir mücadele var. Bir taraftan ölüme doğru çă̆ıran ses, diğer tarafta akordeon sesi. Akordeon sesi nakarattır. Bir tarafta dörtnal, öbür tarafta nakarat ve ses kendi dünyası içerinde ne yapıyor; bize sinematik bir evren sunuyor diye düşünmekteyim. Karakterlere bakıyorsunuz; yani herkesin duyum-motor mekanizması bozuluyor. Biz, klasik filmlere alışkın olan bizler, hatta modern filmlere alışkın olan bizler, anlamsızlığın evreninde, yani karakterlerin konuşmaları, hareketleri ve iletişimsizlikleri üzerinde bir evrenle karşılaşmaktayız. Yani bu karakterler birbirlerini de anlamıyorlar, sözcüklere yüklenen anlamlar farklı. Herkes birbirini duyduğunu zannediyor ama aslında ciddi bir yabancılaşma, ciddi bir iletişimsizlik var; bir anlamsızlık evreni. Acaba kıyametin göstergelerinden birisi bu değil mi? Fakat acaba sorulacak sorulardan birisi, bu kıyamet bizi gelecekte bekleyen bir kıyamet mi? Yoksa şu anda var olan bir şey mi? Dolayısıyla bana göre, kristal imaj; yani geçmiş, şimdi ve gelecek iç içe geçiyor filmde. Geçmiş, ne demek? Dikkat ederseniz bir yer var, deniz kıyısında bir yer. Dikkat ederseniz hemşirenin başlı̆̆ında bunun aslında geçmişte bir yer olduğunu düşünüyorsunuz belki 60'l1 yıllar, 70'li yıllar bilemeyiz ama yani şu ana ait bir alan değil, mekân değil diyorsunuz, zaten kullanılan araçlara bakıyorsunuz mekânlara bakıyorsunuz, bunlardan da hissediyorsunuz. Ama diğer taraftan sözü edilen meselelere girdiğinizde yani nedir o? Çocuk tacizi. Nedir o? Şüphe, herkesin birbirinden şüphelenmesi ve aynı zamanda cinayetler, sebepsiz yere cinayetler. Düşünüyorsunuz, yani bu acaba şu anda var olmayan şey mi? Dolayısıyla şimdiyi anlatan, her gün karşılaştığımız, her gün gazetelerde, medyada karşılaştığımız, sözünü ettiğimiz bir evren var, aynı zamanda şimdiyi anlatıyor. Aslında gelecek değil, distopik bir evren değil sadece. Hem distopya, hem şimdi, hem geçmiş iç içe geçmiş. Dolayısıyla böyle bir kristal imajdan da söz ediyorsunuz. Belirsizlik söz konusu 
ve bu da bizim ne yapıyor, düşünmemizi zorluyor. Ve bu noktada yani ben fazla sözü uzatmadan, acaba Tayfun Pirselimoğlu'nun kurduğu evren benim burada tahayyül ettiğim evrene benziyor mu? Ya da sizin düşünceniz bu evreni kurarken neydi? Sizin de dünyanızı biraz öğrenme imkânımız var mı?

Tayfun Pirselimoğlu: Siz hepsini anlattınız zaten...(gülüşmeler). Şöyle, öncelikle burada olmaktan dolayı çok keyifli ve mutluyum onu belirtmek isterim. Kıyamet. Bir kıyamet filmi yapmak istedim evet. Çünkü dünyanın gidişatının bir kıyamete doğru bir menzilde olduğunu düşünüyorum ve bununla alakalı bir hikâye çok uzun zamandır kafamın içerisinde dönüp duruyordu ve benim daha önce yazdığım bazı hikâyelerde de bu tema çok belirgin olarak var. Fakat esas benim motivasyonum, bu filmi yapmaktaki motivasyonum sahiden sizin anlattığınız gibi; bu, şu anda yaşadığımız hikâyenin bizatihi aynen bunu işaret ediyor olması ile alakalı ve zamanla ilgili söylediğiniz şey de çok doğru, yani biraz Bergssonvari bir şey bu; şu an ama geçmiş ama geleceğin iç içe girdiği bir zaman, tanımlanamaz bir zaman içerisinde yapmak istedim bunu. Dolayısıyla, bu zamanın belirsizliğine eşlik eden bir de mekânın belirsizliği var ve bu her yer olabilir. Ben bunu Trabzon'da çektim ama o dünyanın herhangi bir yerinde bir kasabada da olabilirdi. Bu bütün bu belirsizliklerin amalgaması olarak, yine sizin kullandığınız kelimeyi kullanacağım, bence filmin esas üzerinde durduğu şey, bir sıfat arayacak olursak; manasızlık. Yani bir anlam veremiyoruz. Şu anda yaşadığımız hiç bir şey yani rasyonun kaybolduğu, dolayısıyla izanın buharlaştığı bir zaman. Filmin içerisinde olan bitenleri de konvansiyonel bir sinema içerisinde anlamlandıracağımız şeyler olarak karşılaşmıyorsunuz. Dolayısıyla bu, tabi ki oradaki, film içerisindeki her bir nesnenin, her bir karakterin benim dimağımda bir karşılığ var ve temsil ettiği bir şey var. Olan bitenlerle alakalı benim tasarladığım bir takım hikâyeler var, lakin benim yapmak istediğim sinema benim kendi tasarladığım bu dünyanın seyircideki karşılığının ne olduğuyla alakalı. Yani, ben daha önce de bunu çok tekrarladım, şöyle bir sinema yapmak istiyorum ben; bir takım sorular, seyircinin izleyicinin sorularla ayrılması gerektiği bir sinema deneyimi. Burada, bu, herkesin kendi hakikatini kendi bilinci üzerinden inşa etmesiyle alakalı; yani burada bir benim söylediğim ve işaret ettiğim şeyin sadece seyircinin kendi zihninde ne oluşturacağıyla alakalı açıkçası ve bunu çok kıymetli buluyorum. O yüzden şey bir sinema peşindeyim, izleyicinin zihninde birtakım tohumlar atmaya çalışan bir sinema yapma peşindeyim. Dolayısıyla bu filmde bunlar had safhada var. Belki de bu işin, kendi sinema kariyerim içerisindeki şahikasıdır bu anlamda. Yani benim sinema anlayışım, böyle konvansiyonel, sizde çok iyi biliyorsunuzdur, konvansiyonel sinemayı çok tehlikeli bulduğum için kendimce böyle bir yoğurt yemeye çalışıyorum. O zaman da ortaya böyle bir karmaşa çıkıyor seyirci adına.

Lale Kabadayı: Ben de, yeni tanıştığımız arkadaşlarımız var, izninizle önce kendimi tanıtayım. Lale Kabadayı, Ege Üniversitesi, İletişim Fakültesi, Sinema Anabilim Dalı Başkanıyım. SineFilozofi dergisinin de iki yıllığına editörüyüm. Henüz ilk altı ayımızı tamamlamak üzereyiz. Ben de misafirinizim bugün Ankara'da. Tayfun hocanın filmini izlerken belleğimde oluşan birkaç imaj var, onlar üzerine kısaca bir değerlendirme yapıp sonra hocaya sorumu sormak istiyorum. Biraz önce kendisinin de belirttiği gibi rasyonel olanın kaybını anlatırken usu harekete geçirmeye çalışan bir sineması var. Bu bir çelişkiymiş gibi gelebilir ilk başta ama aslında zor bir yoldan aslında aktif bir izleyiciyi hedefliyor olduğunu gösteriyor çünkü siz 
artık her şeyin anlamını yitirdiği bir evrende anlam ya da anlamsızlık üzerine düşündürmeye çalışarak bile bir anlam arayışını tanımlamış olursunuz. Bunun farkına varıyor mu her izleyici, bundan emin değilim ama hiç olmazsa hissediyor olabilmesi bence bir sinemacının görevini tamamladığını gösteriyor. Yani görev atfı da böyle bir görevi vardır, bunu yapmalıdır gibi bir şey değil, sanatın paylaşılması anlamında bunu dile getiriyorum. Bu nedenle bilinçli ya da bilinç dışı olsun olmasın, izleyicinin oradaki sıkılma hissi belki, dışa vurduğu bir hareket, onun üzerine geliştirmiş olduğu bir düşünce, bunların hepsi Yol Kenarı ile hareket geçen, bu nedenle de aktif izleyiciyi tanımlayan, isteyen, o talepte bulunan bir sinema. Bu yüzden ben filmi çok olumlu değerlendirdim. İçine kapanmış bir kasaba var. Normalde biliyorsunuz ana akım sinemada, eğer deniz kıyısındaysanız bir ferahlama olacaktır, ya da işte yeniden doğuşun bir simgesidir. Suyun içinden biri çıkar falan ki burada da öyle bir karakterimiz var sonra suya geri dönmek istiyor ama nasıl içine kapanmışsa, o "introvert" mi diyoruz hocam? O nasıl bir çıkışsızlık duygusuysa o su o ferahlamayı asla burada getirmiyor. Bizim şiirden alışık olduğumuz ve belleğimizde yer alan giden ve geri dönmeyen gemi benim için o anlamdaydı. Biraz önce dediğiniz gibi sıradan bir izleyici olarak ben o anlamı aldım; giden hiç bir geminin geri gelmemesi. Ama Serdar hocamızın dile getirdiği gibi sürekli o sur borusunun çalınıyor olması ama gemide hiç kimseyi görmüyor olmamız sonun geldiğini çok güzel çağrıştırıyor. Bununla birlikte anlamsızlığa alışmamızla ilgili çok güzel bir gönderme var. Filmin açılışından itibaren gördüğümüz şey, geminin orada sabit durması, ona bakan insanlar.. Bir süre sonra o kadar alışık hale geliyorlar ki, yine gemiye bakıyorlar ama gerçekten artık gemiyi görüp görmediklerine bile inanamıyoruz. Çünkü bu anlamsız yapı kendi kendine bir anlam üretiyor, o andan itibaren geminin orada ertesi gün ve ertesi gün de kalıyor olması bir güven duygusu yaratıyor oradaki insanlarda ya da bir anlam haline dönüşüyor. Ne zaman ki o gemi ortadan kayboluyor ya da batıyor dediğiniz gibi ya da başka bir biçime forma giriyor, artık bizim için görünmez hale geliyor. Belki sis iniyor ya da işte ufuk çizgimizin tamamıla kaybı nedeniyle gemi orada olsa bile biz artık onu göremiyoruz. Yeni bir anlamsız evreniyle tanışıyoruz. O halde katmanlı ilerleyen bir yapısı var filmin ve hep anlamın peşinde koştuğu bir yapı bu. Çok tekinsiz bir yapı, insanı endişelendiriyor sıradan bir izleyici olarak. Nasıl tanımlamalıyım? Çünkü kendimi o evrende o gemiye bakan o erkeklerin yanında duran biri gibi hissettim. Onların eril bakış açısından okunması gerekip gerekmediğini belki tekrar sormam mümkün olabilir. Kadın temsilleri üzerine konuştuğumuzda yeri gelebilir. Ama bakılmanın verdiği etkenliğin dışında aslında o geminin bize baktığı duygusunu hissettim, bu yüzden de kendimi edilgen hissettim ama biraz önce çelişkide olduğu gibi, aynı zamanda düşünmemi sağladığı için (çok karmaşık anlatıyorum, kusura bakmayın) etken bir izleyici konumuna geldim. Doğru mudur? (gülüşmeler)

T.P: Burada yanlış yok zaten. Yani demin de onu anlatmaya çalıştım. Bu benim yapmaya çalıştığım sinema, izleyici ile kurduğum bağın sezgisel bir düzlemde oluşmasına çabalıyorum. Dolayısıyla her izleyici için buradan üretilecek anlamlar var sezgisel olarak. Yani bu, sizin anlattığınız gibi filmin hikâyesinin içerisindeki belirsizlikler, her izleyici için kendince anlamlandıracağı bir mana taşıyor. Dolayısıyla söylediğiniz her şey doğru, söylediğiniz her şey yanlış. Bu, demin de altını çizmeye çalıştığım gibi, bu izleyicinin kendi hakikat tasavvuru ile alakalı bir şey. Benim izlediğim bir film var, kendi yaptığım filmi izlediğim zaman 
gördüğüm bir şey var fakat bunun karşılığı sizde aynısı olmayabilir. Bu, bazılarına anlaşılmaz gibi geliyor fakat bence kıymetli sinema da bu. Yani bizim bir filmin iyi olduğuna ya da kötü olduğuna karar vermemiz sadece kişisel bir tecrübedir, o da ancak sezgisel olarak varılabilecek bir noktadır diyebilirim. Yani bunun birçok örneği var, dünyada. Hiç bilmediğimiz bir hikâye anlatan ama bize çok çarpıcı gelen birçok film var, benim var mesela çok. Buradaki şey o filmin bana anlattığı hikâyenin bendeki karşılığının benim için çok kıymetli ve değerli olasıyla ilgili bir şey. Dolayısıyla sizin de soracağınız sorular varsa, hiçbir şekilde benden tam bir karşılık alamayacaksınız. Yani ben kendi hikâyemi kendimde saklıyorum, benim için kıymetli olan şey sizin bu filmi izledikten sonra bunun üzerine bir tefekkürde bulunmuş olmanız ve bunun üzerine düşünmüş olmanız, bununla ilgili bir fikir üretmiş olmanız. Ama bence sanatta doğru ya da yanlış diye bir şey yok. Kıymetli olan bir şey var kıymetsiz olan bir şey var ve ben bu kıymeti de kendi sinemam içerisinde, işte deminden beri anlatmaya çabaladığım şekilde, ben sadece böyle bir şeyler ortaya atarak, kendimce çok anlamlı şekilde doğru yerlere attığımı düşünerek, bir takım fikirler atıyorum ve bu da seven için bunu aldığı zaman bununla alakalı bir heyecana kapılıyor, bir haz doğuyor. Dolayısıyla bu film içerisindeki çok informatik de gelebilir, birçok bilmeceler sorabiliyor olabilir ama işin iyi zamanda çok bilmece soran ve izleyicisinden onun cevabını talep eden sinema olduğunu düşünüyorum. Durup durup hep aynı şeyi anlatıyorum ama bu filmle alakalı dediğim gibi, şunun manası aslında buydu ama siz onu böyle anlamışsınız diye bir şey söylemeyeceğim ben. Bunu hem size hem kendime haksızlık sayarım ama böyle bir filmle alakalı herkesin hikâyesini dinlemek isterim tabi ki. Ve belki sizin hikâyeniz muhtemelen benim kurmak istediğim hikâyeden de daha enteresan da olabilir. Benim yapmaya çalıştığım sinema böyle absürt tuhaf bir şey yani... O yüzden... Doğru yerdeyim herhalde (gülüşmeler).

S.Ö: Yani sizin söyleminizle gidelim, doğru ya da yanlış yoktur...(gülüşmeler). O zaman bu hikâye parçalarını biraz bir araya getirmek için acaba konuklarımız ne düşünüyorlar? Onların bu hikâye parçalarına yönelik katkıları ne olacak?

T.P: Ya da ben biraz daha bir şeyler açıklamaya çalışayım en azından. Yani bu dünyanın sonu hikâyesi, bu eskatolojik edebiyatı çok seviyorum ben çünkü bir sona gelmekle ilgili bir derdim var benim. Yani bu bütün filmlerimde de olan, ölümle alakalı ilişkilendirilebilecek bir şey bu. Bir sona geldiğimizi düşünüyorum hakikaten. Fakat bunun, beni karamsar bulanlar var bu konuda, bir sonu işaret ettiğim için. Fakat ben bunu çok olumlu buluyorum, çünkü bunu da defalarca anlattım ama bir sona gelmemiz gerekir ki yeniden başlayabilelim diye. Bu bir çemberin üzerinde yol almakla alakalı. Bu çok determinist bir bakışmış gibi görünebilir, bence son derece diyalektik bir şey çünkü bir sona gelmemiz gerekiyor ki yeniden başlayabilelim. $\mathrm{Bu}$ da benim kendi dünyamda son derece olumlu bir yere tekabül ediyor ve bu kıyamet filmi bence olumlu şekilde bitiyor. Yani filmin işaret ettiği finaldeki son sahneyi de koymama rağmen, yine de bu çember tamamlandı ama tekrar başlıyor, başlayacak ya da gibi bir şeyi de işaret ediyor. Yani anlatmaya çalıştığım, bu, bir çemberi tamamlayarak yolun sonuna gelme hali, bütün filmlerimde var benim. Bütün filmlerim benim nasıl başlıyorsa öyle biter. Bu film de öyle oldu ki bu film bizatihi bunu anlatan bir film ve israrla da ben bunu anlatmaya devam ediyorum yani obsesif bir şekilde bir son ve başlangıçla alakalı bir derdim var muhtemelen. 
Bu hayat ölümle ilgili de açıklanabilir belki de. Böyle bir üçleme de yaptım bunun üzerine.. Öyle.

L.K: Bu her zaman bahsedilen işte mağara duvarlarına çizilmiş olan mesela İsmail Gezgin'in bu konuda güzel bir kitabı var, "Sanatın Mitolojisi” diye. Oradaki boynuzlu hayvanın aslında ava çıkıldığında avlanacak değil, ölümle mücadele eden insanlar olduğunu tanımlıyor İsmail Gezgin. Bu ölüme karşı aynı zamanda merak duymak, ona direnmek, kalıcı olmayı düşünmek, bunun için bazen çocuk doğurmak, bazen sanatı eseri bırakmak. Galiba bütün bu sorular felsefenin yüzyıllardır tartıştığı ve bizim de yalnız olmadığımız sorular ve siz de hem resim sanatınızda hem edebiyatınızda hem sinemanızda bununla ilgili, tabiri caizse kendi payınıza düşenin hakkını veriyorsunuz diye düşünüyorum. O yüzden bu kıyametin yaklaşmış olması ama hala yeniden doğacak olmanın ya da yeniden hayatta kalacak birilerinin olmasının bir umut olarak okunması gerektiğini düşünüyorum. Doğru mu?(gülüşmeler)

S.Ö: Ben de orada bir şey söyleyebilirim belki. Filmde umutla ilgili bir kaç imaj da var zaten..

T.P: Bir kaç tane de olsun... (gülüşmeler)

S.Ö: O distopik denilen dünyanın içerisinde, o çember dünya, bengi dönüşüm içerisinde, çocuğun gülümsemesi. Yani temizleyici 1 diyorum ona, siyahlar giymiş olan, derin devleti belki temsil eden kişi, temizleyici 1. Temizleyici 2 de yerleri süpüren kişi. Temizleyici 1 , temizleyici 2 tarafından vurulduktan sonra, dikkat ederseniz eve gelir ve çocuk ona gülümser. Bu gülümseme filmde gördüğümüz tek gülümsemedir. İstisnadır, filmde istisnadır ve çocuk tarafından sergileniyor. $O$ istisna bize gelecek toplumun nasıl olabileceğine dair ipuçları vermesi açısından önemli. Bengi dönüş nasıl olacak? İki, temizleyici 2 ne yapıyor, yerleri süpürüyor. Diğerleri vicdanlarını rahatlatmak için sürekli varoluşsal konuşmalar yapıyor ve eylemleri onlara hiçbir şekilde uymuyor ama temizleyici 2 aslında neyse o şekilde konuşuyor. Yani "bilmiyorum "diyor. Bilmiyorsa bilmiyorum. Diğerleri anlam biçiyor, yani hikâyeler yaratıyor. Yani temizleyici 2 hiçbir zaman vicdanını rahatlatmak için konuşma sergilemiyor. Bir de ona dikkat etmemiz gerekir diye düşünmekteyim. Üçüncüsü akordeon sesi. Yani son derece yaşamı olumlayıcı bir ses ve bu ses de yine nakaratı sağlayan, direnen bir ses, üç. Belki bir tane daha söyleyebilirim; denizden gelen kişi. Denizden gelen ama hiçbir şekilde konuşmayan, konuşamayan çünkü demek ki var olduğu dünya o kadar bir dibe inmiş ki çukur haline gelmiş ki, o anda artık konuşamıyor, zaten öldürülüyor, daha sonra diriliyor ve tekrar yaşama dönüyor. Yani bengi dönüş. Yani doğru olabilir, yanlış olabilir, sadece bana, siz sezgisel sinema yaptığınızı söylüyorsunuz, bana da sezgisel olarak şunu hatırlatıyor; gemi var, Zerdüşt'ün gemisi, geminin içerisinden gelen bir karakter var, bana sanki geleceğin toplumunu anlatan üst insan gibi geldi bana ve sonra tekrar denize gidiyor çünkü Zerdüşt de insanların halini gördükten sonra zor konuşuyor, yani onlara hitap etmek istiyor. Yani bunlar hep umut. Deniz keza. Bir taraftan kara var, öbür taraftan deniz. İkisi arasında da bir çatışma var çünkü karasal birim serttir. Deniz ise bize ütopyayı anlatır. Zaten Thomas More'un "Ütopya"sını biliyorsunuz. Yani ilk defa kara ile deniz yan yana geliyor, ütopyayla distopya da yan yana geliyor. Yani böyle bir kristalleşme de söz konusu orada. Bengi dönüşü de rahatlıkla görüyorsunuz. Nietzsche'nin zaten felsefesinde de biliyorsunuz bir şeyi yıkmak gerekiyor önce. Yeniyi yaratmak için önce bir şeyi tamamen yıkmak gerekiyor. Bu da bu 
açıdan önemli diye düşünmekteyim. Bu noktada ne yapalım? Seyircilere hikâyelerini tamamlamaları için...

T.P: Sizin hikâyelerinizi merak ediyoruz.

S.Ö: Sizin hikâyelerinizi merak ediyoruz evet.

Aysu Uğur: Hoş geldiniz öncelikle. Emeğinizi sağlık. Ben filmi izlerken gerçekten de o kasabada sıkışık kalmış gibi hissettim ve aslında nerede olduğumu da tam olarak bilmiyordum. Ben biçimle ilgili bir şey soracağım. Filmin kurgusu da çok alışık olduğumuz türden değildi, daha deneysel bir kurguydu. Acaba sürekli ekranın sekanslar arasında kararıp tekrar açılması seyirci için bir nefes alma mı yoksa durum ve insanlar arasındaki kopukluğu sergilemek mi? Siz bunu nasıl düşünerek böyle bir kurguyu tercih ettiniz, bir anlamı var mı?

T.P: Şöyle bir anlamı var. Bu hikâye aslında lineer bir hikâye değil ve bu biçim olarak da, nasıl üslubu biraz aykırı duruyorsa biçim olarak da, bu hikâyenin beni zorladığı bir şey var, ifade etme biçimi var. Dolayısıyla bu hikâyeyi kurarken, yani şöyle bir hikâyeyi tasarlıyorsunuz, senaryo haline getiriyorsunuz, sonra çekiyorsunuz, sonra elinize bir malzeme geliyor ve o zaman görüyorsunuz ki, bu hikâye ancak böyle anlatılabilir. Yani sizin kurguladığınız başta bir hikâye var fakat sonra onları, o sekansları yan yana getirdiğiniz zaman o sizi bir şeye doğru zorluyor. Tabi kendi üslubunuzun limitleri içerisinde. Dolayısıyla bu kararma açılmaların, siyaha düşmelerin, bu hikâyenin bizatihi zorladığı bir ifade biçimi olduğunu düşündüm. Kurgusunu Ali ile yaptık, Ali Aga. Çok yetenekli bir arkadaşım. Bunun çok üzerinde yani, bunun bizi zorlamasını birlikte tartıştıktan sonra, bu hikâye böyle ancak gösterilebilir diye bir karar aldıktan sonra böyle yaptık. Demin de onu anlatmaya çalıştım, yani bir yönetmen olarak ürettiğiniz filmin aslında bir yerden sonra sizi elinizden tutup, edebiyat da böyledir aslında bir şey yazarsınız, başladıktan sonra o sizi alır bir yere doğru götürür. Benim yaptığım sinemada da bunu çok yaşıyorum ben, yani bütün incelikleriyle tasarliyorum fakat sonra, bir yerden sonra o sizi tasarladığınız yoldan çıkartmadan başka bir yoldan bir yere doğru götürüyor. Dolayısıyla bu filmin biçimi de kendisini icra ettiği şekilde oldu. Onu söyleyebilirim.

Esra Güngör: Tekrar hoş geldiniz öncelikle. Kıyametle ilgili ben o umut hakkında olabileceğine dair bir soru soracaktım size, ama biz sormadan siz cevaplamış oldunuz. Ama bizde de, mesela arkadaşlarımızla konuştuğumuzda, onu belirtmek isterim ki nihilist bir tutumdan çok umutvari bir dünya inşasına dair bir tasavvur olduğunu biz zaten düşünmüştük. İkincisi, filmde bir kaos ortamı var ve dışarıdan gelen, sonradan o kasabaya dahil olan kişiden bir medet umma ya da sorunlarının kaynağında onu görme var. Aslında benim dünyamda, benim algı inşamda bu şöyle; biz toplumsal olarak sorunlarımızın kaynağını dışarıdan gelen olarak gördükçe ya da yine keza bir çare, dert, deva arayışımızı yine kendi içimizde değil de dışarıdaki kişide aradığımız müddetçe bu sorunların sanki hiçbir zaman çözüme ulaşamayacağını ancak bunun sona ermesiyle beraber yani toplum kendi içine dönüp kendi sorgusunu bireyden başlayarak yapabilirse ancak biz gerçekten bu toplumsal yapıdaki sorunlara, görünür kılınan sorunlara çözüm bulabiliriz gibi bir algı inşası oluştu. 
Sizin bu dışarıdan gelene toplumun bakışı hakkındaki görüşleriniz neler olabilir, onu merak ediyorum?

T.P: Şöyle kurmaya çalıştım açıkçası burada, aslında Tansu'nun (Tansu Biçer) oynadığı o karakter sonradan kasabaya gelen, aslında bütün hikâye onun etrafında dönüyor. Şöyle bir oyun, gerçek anlamda teatral bir oyun kurmak istedim orada. Dolayısıyla oyunculuklarda dikkat ederseniz ona uygun bir şekilde aktarılıyor. Bizim, en azından bu toplum için söyleyebilirim, insani iffetlerimizden bir tanesini birine bir şey atfetmekle ilgili ve ona atfedilen, onun talep etmediği halde atfedilen bir kimlikle karşılaşıyor ve aslında film biraz da hikâyenin burasıyla da gedikliyor_diyebilirim. Bu sizin söylediğiniz gibi toplumsal problematiği ile ilgili de bir şeyler söyleyebilirim. Ben daha çok orda daha deruni bir şeyi anlatmaya çalıştım, bir problemi. Yani Mehdi Deccal hikâyesi aslında bir yer de, Kim Mehdi, kim Deccal? Ve bizim israrla bir kurtarıcı beklememiz ile ilgili ve bizi ancak birinin kurtarabileceğini ama aslında o, gerçekten o mu ondan çok emin olamadığınız bir hikâye devamında. Yani bir kaç katman var sahiden ve onlardan bir tanesi de sizin söylediğiniz gibi bir şeye işaret ediyor, böyle bir hikâyeyi anlatıyor.

Süleyman Duyar: Ben öncelikle yazar olan Tayfun Pirselimoğlu'nu, yönetmen olan Tayfun Pirselimoğlu'ndan önce tanıdığım için film beni açıkçası çok şaşırtmadı. Daha önce okuduğum şeyleri tekrar izliyormuşum gibi geldi bana.

T.P: Film aslında benim yazdıklarıma, daha önce yaptığım filmlere göre daha yakın duruyor.

S.D: Şeyi düşündüm ben film boyunca, filmdeki bütün karakterler birbirlerinin yerine ikame edilebilir şekilde filmin içerisine dahil oluyor ve hani karanlığın, aydınlığın, karanlıktan, aydınlıktan tam emin olamıyoruz. Hatta ana karakter gözünü ışıkların gidip geldiği zaman açıp kapatıyor ve ona alışmaya çalışıyor ama yine de 1şıklar gidiyor. Film içinde 1şıklar söndüğü anda aslında film bitiyor. Filmin olup olmadığından bile emin olamayabiliriz yani aslında bu noktada ve ilk bakan adamlarda açıkçası ben ilk sahnede açıkçası kör olabileceklerini düşündüm çünkü hani cezmi karanlık şeyinden dolayı, nasıl diyeyim? Tanık olduğu olaylar, kan davası olduğu adamın kör olması gibi falan...

T.P: Bu kör takıntım da var benim evet... (gülüşmeler)

S.D: Evet, o adamında kör olabileceğini düşündüm, bir gözü şeydi.

T.P: Bu arada söyleyeyim, Deccal'ın sol gözü körmüş.

S.D: Evet, onlar aklıma geldi. Ayrıca televizyonda bir şey var, millet, devlet propaganda, görüntü gidip geliyor ve eğlence ile iç içe gelmiş. Bir eğlence devam ediyor ama ideoloji ile iç içe geçmiş.

T.P: Daha doğrusu orada mesela televizyonun işlevi biraz benim tasarımda şöyle bir şey, o hep açık ve aslında kimsenin seyretmediği, ya da baktığı ama seyretmediği diyebilirim ve tam da belli olmayan, sadece bir noise dediğimiz var ya, belirsiz bir görüntünün nerdeyse hipnotize ettiği ve böylece alışkanlık yarattığı bir medium. Bu televizyon benim bütün filmlerimde vardır, çünkü bir de mesela bu filmde de var, bana soruyorlar, her seferinde 
soruyorlar, mesela çok sigara içiliyor. Bu filmde yine o kadar yok ama çok yemek sahnesi severim ben çünkü bu üç şey yani; sigara içmek, yemek yemek ve televizyon izlemek şehevi bir şekilde insanoğlunun aşağılık bir tarafını gösteriyor, yani tüketmek üzere, başka bir yere atladım ama şimdi sırası geldiği için söyleyeyim. O yüzden bu üç eylemi, bütün filmlerimde altını çize çize kullanmamın bir nedeni de bu. Buradaki televizyon, dediğiniz için söylüyorum, buradaki televizyon ama daha önce kullandıklarımdan biraz daha farklı bir şekilde, ideolojik bir aygıt olduğunu iyice belirleyen bir şeklide kendini gösteriyor.

S.D: Ayrica hamam sahnesinin, hamamin,

T.P: Bir takıntım da hamam evet... (gülüşmeler)

S.D: Tek gerçek mekân olarak kurguladığınızı düşündüm çünkü kamusal bir alan ve kamusal temizlenme alanı ve idea isimli süpürgenin orada işlememesi nedeniyle onun diğer bütün gerçek yaşam mekânlarının gerçek değil ama sadece hamam mekânının gerçek olduğunu düşündüm.

T.P: Hamam şöyle, hamamı böyle temizlenme, arınma mekânı olarak tasavvur ediyoruz. Bunun sahte bir şey olduğunu da göstermek istememle de ilgili bir şey, Yani böyle temizlenemeyiz aslında, benim özellikle Saç filmimde bunun fazlasıyla altını çize çize gösterdiğimi düşünüyorum ama madem takıntılara geldi sıra bir de biliyorsunuz otel takıntım var. Bu filmde de var otel, bütün filmlerimde var otel. Otellerden çıamiyorum ben, bilmiyorum niye.. "Otel Odaları" diye de bir hikâye kitabım var benim. Sadece otellerde geçen hikâyeleri yazdım. Galiba şey gibi geliyor, daha ileri gidemediğimiz bir kompartıman ve bu bana çok trajik geliyor. Buradaki otel de biraz onu çağrıştırıyor evet.

Frrat Osmanoğlulları: Ben biraz aslında şeye benzettim, ikinci yeni şiirin akış biçimine benzettim filminizi. Özellikle Ece Ayhan şiirinin akış biçimine. Ece Ayhan şey diyordu sanırım, günlüğünde ya da denemesinde, yeni bir düşünce için yeni bir dile de ihtiyaç vardır. Hani bunun sinemada karşılığını da Godard' da gördük, Godard' da görüyoruz hala. Bu filmin ben Türkiye sinemasında da, dünya sinemasında çok benzerini görmedim. Evet, parçalara bölersek; kurgu benim için yeniydi, değişikti, artık siyah beyaz film çeken de çok yok, oyunculuk kullanımız keza, biraz daha farklıydı, daha tepkisiz, belki bir derece Bressonvari bir oyunculuk vardı, ses kullanımınız yine farklıydı ve yeni bir düşünce biçimini zaten az önce fazlasıyla konuştunuz. Ben burada yeni bir dille, yeni bir düşünce biçimini, bir düşünce biçimini yeni bir dille anlatış çabası gördüm şahsen ve bununla paralel olarak şu da aklıma geldi filmi izledikten sonra. Bir arkadaşım yine Ece Ayhan şiiri üzerine şöyle demişti; Ahmet Arif' in ya da Nazım Hikmet' in şiirini söyle sana ezbere okuyayım ama Ece Ayhan'ın bir şiirini söylediğin zaman ismini, şiiri biliyorum ama tek kelimesi aklıma gelmiyor, sadece imajlar gözümün önüne geliyor. Bende de aslında benzer bir şey oldu. İnsanların birbirlerine ne dedikleri, nasıl davrandıklarından ziyade, sadece imajlar geliyor kafama ve imajlarla ilerleyen bir biçim tahayyül ediyorum sadece. Bana çok farklı geldi bu açıdan, bilmiyorum

T.P: Çok kıymetli bu söylediğiniz. Ece Ayhan benzeşmesinden onur duyarım. Evet, doğrudur, yani bir ölçüde Ece Ayhan'ın cüretini sahiplenmek istiyorum bu anlamda çünkü sinemanın gittiği yeri çok sakat ve manasız, olumsuz anlamda manasız buluyorum. Yani bizim sinemada 
da dünya sinemasında da çok konformist bir sinemanın egemenliğinin olduğunu düşünüyorum. Bundan kastım şu; yani bize bildiğimiz hikâyeleri, bildiğimiz şekilde anlatan, bildiğimiz yönetmen sinemaları böyle ibadullah gibi üzerimize döküyorlar bunları. Bir de bunun bir nedeni de zannediyorum çok fazla film üretiliyor olması. Yani dijitalize olduktan sonra sinema, çok kolay çekiliyor olmasından dolayı. Bu bir tuhaf, kötü bir yeknesaklık, bir vasat oluşturdu ve burada boğulduğumu hissediyorum, o yüzden çok film seyretmiyorum açıkçası. Yani bu bir kibir ifadesi değil asla, sahiden, edebiyatta da öyle, yani elim gitmiyor. Dolayısıyla kendi seyretmek istediğim filmi yapma peşindeyim ve bunun da sinemanın geldiği yerden biraz daha ileriye gitmeyi göze aldığı bir cüretle yapılması gerektiğini düşünüyorum. O yüzden yeni bir dil belki fazla iddialı olabilir ama yeni bir zihin muhakkak olması lazım. Yani bu, bilmiyorum ne diyorsunuz bu dünya sinemasının gittiği yerle alakalı ama benim izlenimim kıyamet alameti olduğu görüşü sinemanın geldiği yer.

Hayriye Özel: Aslında bunu da, şöyle bir şey, şu an biz hani distopyanın içindeyiz. Yani aslında film yani yaşadığımız dünyayı estetik düzeyde tekrar aslında ustadan ustaya bir aktarım diye görüyorum ben sizin filminizi çünkü hani belirli bir şeye sahip olmayan veya şu anki durumu içinde mutlu, sadece seyreden olarak hani bakar ve sıkılır çıkar. Ama hani belirli bir üslubun içindeki bilinçli ve farkında olan kişi evet ya şimdi burada bu dünyada yaşıyoruz zaten şimdinin içindeyiz ve bu hani izliyoruz diye düşünür. Yani filmin zamansız, mekansız, isimsiz olması da aslında tüm dünyanın hani evrensel bir şey yani bence hani haddim olmayarak söylüyorum, başarmışsınız yani evrensel bir şeye getirmeye. Her yerde geçer yani zamansizdir.

T.P: Evet öyle bir şey yapmaya çabalıyorum. Yani şunu biliyorum, bu sinemanın tüketiciyle kuracağı, kurduğu ilişki daha önceki tecrübelerimden de ne olduğunu bildiğim için, mesela bu filmi işte 2500 kişi gördü.

H.Ö: Ustadan ustaya mektup diyorum, hani bilenlerin anlayacağı ve fark yaratacağı.

T.P: Böyle elitist bir sinema yapma peşinde değilim asla ve kat'a fakat bu sinemanın, deminden beri anlatmaya gereksindiğim şey böyle bir sinemayla, yani bu da fazla iddialı bir ifade olacak diye korkuyorum; fakat sinemanın ancak böyle kurtulacağını, edebiyatın, sanatın bizatihi kendisinin böyle ancak yol alabileceğimi düşündüğüm için bunu yapıyorum yoksa bunun karşılığı olmadığını biliyorum. Tabi şurada bunu konuşuyor olmak benim için çok değerli ve sırf bunun için bile bu filmi yapmaya değer benim için. Fakat onun da ötesinde ben bir tane seyirci bile olsa, o da olmasa kendime, seyrettikten sonra benim için bir haz vesikası olarak tanımlayabileceğim, memnun olacağım bir film yapmak bile sadece benim seveceğim bunu yaparım. Bu seyirciyi kaile almıyorum anlamında değil fakat sırf seyircinin isteğine uygun bir sinemayı asla yapmayı düşünmedim hiç.

E. G: Zaten seyircinin belki de beklentileri uzun yıllardır inşa edilmiş olduğu için bu, hep o imajları görmeye alıştırıldığı için...

T.P: Bu çok uzun değil, onu söyleyeyim size, bu seyircinin zihninin buraya gelmesi çok uzun zaman almadı, bence 15-20 yıllık bir hikâye. 
E.G: Bence yine değişebilir böyle filmler sayesinde diye düşünüyorum. Böyle filmlerle karşılaşmalar arttıkça. Yani belki bir anda iki milyonun beğenisi, ya da işte izleme alışkanlığında bir değişim olmasa bile zamanla iki milyona da ulaşacağını umut ediyorum ben şahsen.

T.P: İnşallah öyle olur ama...

H.Ö: İnsanlığın da değişmesi gerekiyor herhalde değil mi? Çünkü haberlerde tecavüz olayları şunlar bunlar o kadar normalleştirildi ki ve kanıksandı. Hadi sizdeki o sadece konuşup ama eyleme geçmeyen insanlardan oluşan çoğunluğun olduğu iki milyona erişirse eğer hani çok güzel bir şey o zaman demek ki zihinsel ve...

T.P: Yani olur mu olma mı bilemem ama bana şeyi hatırlattı; Hegel ve Schopenhauer aynı üniversitede ders veriyorlarmış, Hegel'inki dolup taşarmış, Schopenhauer'a kimse gitmezmiş, o dersini anlatmaya devam edermiş. Ben asla kendini öyle ifade etmeye çalışan Schopenhauer değilim gayet tabi fakat onu anlayabiliyorum yani.

S.Ö: Hegel'in ideasını o yüzden mi süpürge yaptınız? (gülüşmeler)

T.P: Aşırı yorum diye bir şey de var biliyorsunuz... (gülüşmeler)

L.K: Schopenhauer da inatla Hegel'in saatine koyarmış özellikle hani ana akım sinema anlatılışı.

H.Ö: Yine bir umudu var, artacak mı?

T.P: Schopenhauer umutsuzluk ve kötümserlik anlamında bana uyuyor doğrusu...

Esra Keloğlu İşler: Biz filmi akşam yorgun argın, müthiş bir yağmurdan sonra zorlukla sinema salonuna ulaşarak seyrettik. Ben varoluşçu felsefeyi çok severim ve filmi de çok varoluşçu buldum. Jean Paul Sartre' ın Bulantı'sındaki gibi yoğun bir "angoisse" (sıkıntı) hissi var filmde, içinden çıkılamayan o sıkışmışlık hissini "angoisse" 1 film veriyor bize. İkincisi de "autri" (diğerkâmlı) yani diğerine bakıp kendini var etmek ve diğeri üzerinden anlamlandırmak. Çünkü birisi sana anlamlısın dediğinde anlamlı değilsin ama kendi anlamlarını çözmek için de başkasının aynalık işlevine ihtiyacın var. Bu iki şekilde oluyor; ya kötülük ya iyilikle. Mesela hemşirenin diğerinden kurtulmak için o yeni gelene onu bıçaklatma talebi olabilir mi? Ya da sarılma olabilir mi? Çünkü Jean Paul Sartre'ın varoluşçuluk anlayışında hep başkasının gözünden kendini görebilmek var. Eğer başkasının gözünden kendini göremiyorsan bunu bir din kitabının veya bir başka kişinin şöyle var olacaksın demesi gerçek bir varoluş değil. Bu hikâye de görülüyor filmde bence, tek umut ve kurtuluş sevgi.

T.P: Bu sonsuz bir döngü. Dolayisiyla hep umut var, hep umutsuzluk var. Yani hep yenileceğiz ve sonra tekrar yeneceğiz. Bu devamlı sonsuz bir tekrarın içerisindeyiz diye düşünüyorum ben. Ama bu beni rahatsız eden bir düşünce değil açıkçası, ölüyoruz ama tekrar diriliyoruz. O yüzden benim birçok filmimde, kitaplarımda da var, ölüler geri döner. Yani, mesela buna inanıyorum evet bir şekilde döneceğiz evet geliyoruz. O döndüğümüz, belki biz olduğumuzu anlamayacağız ama o biziz. 
L.K: Sondaki karakterin denize atlayıp atlamama kararını veremeyip geri dönüp bize bakması da galiba.

T.P: İşte son, gene seyirciye bıraktığım bir şey. Acaba atlıyor mu? Atlayacak mı? Yoksa ne yapacak ve size soruyor belki.

L.K: Bir de biz ne yapacağız...

T.P: Ben ne yapayım diyor?(gülüşmeler)

Aydan Özsoy: Hoş geldiniz tekrar. Ben iki üç kişiyle bir deneyimimi anlatayım ki size de buradan feedback olsun. Büyülü Fener'de izlemiştim filmi, yine böyle Esra' nınkine benzer bir deneyimdi, bolca Ankara' nın sağanaklarından sonra sağanaklı ve bol kasvetli bir günde. Aynı şeyi düşündük.

T.P: Ama filmlerin bu kadar az seyirci almasında sağanağın hiç bir kusuru yok. (gülüşmeler)

A.Ö: Sonra o iki kişi de çıktı ben tek başıma filmi seyrettim. Fakat bana baştan itibaren, zaten uzun zamandır böyle bir siyah beyaz film, biz tabi derslerde izliyoruz ama seyirci olarak bir siyah beyaz film ile karşı karşıya kalma hissini yaşamamıştım. Sanki böyle sinemanın o ilk haline dönüş gibiydi. Görsellerin bu kadar etkileyici olması yani, görüntü yönetmenimizin biliyoruz maharetlerini, tıpkı kurguda olduğu gibi... O görüntüler bana saf sinemayı çağrıştırdı. Ben biraz da kendi deneyimlerimi size aktarmak istiyorum ki size de belki biraz katkısı olsun diye. Zaten o sur borusunun çalınışıyla birlikte, yani bir uyanış, seyirciyi dürtme hali, seyirciye kendine gel deme hali, baştan beri konuşmalarınızda da söylüyorsunuz ya, seyircinin de soru sorma hali, ben hep böyle sinemanın o ilk halini bu görüntü ve ses üzerinden.. Ses üzerinden de kurduğunuz bir dünya var, Surla başlayan. Neredeyse üçümüz birden salonda rahatsız olduk aslında. Yani bu tümüyle refleksif bir şeydi ki alışık olmamıza rağmen. Bizler de farklı filmler izliyoruz çoklukla, sıklıkla. Yani onu soracaktım. Bu sinemanın $\mathrm{da}$, çağdaş sinemanın, modern sinemanın bir krizinden bahsediyoruz ya, acaba sinemanın ilk yılları, var mı ipuçları, mesela seyirci açısından da soruyorum. Vertov'dan başlayarak, kameralı adamdan başlayarak, bir onu soracağım. Bir de ikincisi Tayfun Bey, bazı filmlere göndermeler yakaladım kendimce, pastişler vardı. Sanki böyle, Sen Aydınlatırsın Geceyi 'den ki o filmde Onur Ünlü 'nün filmi, Tarkovski'den, Bela Tarr'dan bazı kareler hissettim. Hani böyle mutlaka film çekerken öncesinde sonrasında mutlaka sevdiğiniz yönetmenler vardır. Böyle bir hani, sinemanın kendisine de, ben Türkiye'de oyuncuları da sıklıkla hep aynı kişilerden seçiyor olmanız sanki o evreni tekrar başka öykülerle yeniden kuruyor olmanızı, bile kendinize gönderme olarak da okuyorum bir tarafta. Onu merak ediyorum. Bu göndermeler bilinçli mi? Yoksa benim yorumum mu?

T.P: Göndermeler var ama sizin saydığınız isimlerle alakalı değil. Ama bence kıymetli olan bu. Belki ben bunu bilmeden yapmışımdır, o mümkün. Yani bilinçaltımda sakladığım ve farkında olmadığım birçok şey var ve bir şey yazarken, çizerken sahiden bazen çıkıyor fark ediyorum bazen fark etmeden o oraya akıyor. Yani film yapmak aslında ruhunuzu akıtmak eylemi. Ya da gerçek anlamda bir sanatı oluşturmak, yazmak, çizmek, her ne yapıyorsanız. Sizin kontrol edemediğiniz bir şekilde ne üretiyorsanız ona ruhunuz akıyor. Bu böyle çok 
romantik bir ifadeymiş gibi ama gerçekten en azından benim düşüncem bu yönde, böyle olduğuna inanıyorum. Bu filmde de evet bazı göndermelerim var bir takım isimlere. Ama benim çok sık başıma gelen bir şey yani, başka daha önceki filmlerim de, benim şu sinemacı, bu edebiyatçı filan diye, şuradan gelmiş falan diye böyle çok şeylerle karşılaştım hatta bunu anlatmıştım, belki bilenleriniz vardır. Bir keresinde Ben o Değilim filmi ile Japonya' daydım, bir festivalde, festival başkanı benimle görüşmek istedi. İşte bir saat falan böyle konuştuk, çünkü ısrarla benim yaptığım filmin Kobo Abe'nin dünyası olduğunu söylüyor. Kobo Abe ben hiç okumamıştım doğrusu. Türkçe'ye çevrildi iki kitabı var, bir de seyretmediyseniz mutlaka seyredin, Woman in the Dunes diye bir film var, 60'larda. Onun romanından çekilmiş bir film. Bilmiyordum ben Kobo Abe' yi ama Kobo Abe yapmışım meğer. Dolayısıyla bu sanatın, bizim görmediğimiz başka bir perdenin arkası var, orada biz karşılaşıyormuşuz muhtemelen. Öyle. İkincisi, ilk sorduğunuz soruyla alakalı, saf sinemaya inanıyorum ben. Yani numara yapmayan, seyirciyi avlamak için çaba göstermeyen sinemayı çok kıymetli buluyorum. Belki sinemanın o ilk yıllarındaki o safiyet de buna tekabül ediyor olabilir, o yüzden planlı hareketi olabildiğince yapmıyorum, işte müzik çok az kullanıyorum, bazen hiç kullanmıyorum. Bütün bunlar, bir çerçeve var ve çerçevenin içerisi bile değil onun dışında da bir şeyler oluyor, onu da bir şekilde ima eden bir sinema kurmaya çalışıyorum ve bunun ancak namuslu bir şekilde bu işi yaparsanız çalışacağına inanıyorum. Seyircinin de zaten sıkıntı çektiği şey bu çünkü günümüz seyircisinin zimmi bir ilişkisi var, seyrettiği, tükettiği filmle. $O$ da karşılıklı beni eğlendirecek sinema, bak ben senden şunu talep ediyorum diyen bir sinemaya gidiyor, sinema da ona istediğini veriyor zaten. Bu ilişkiyi çok hastalıklı buluyorum ve bugün sinemanın geldiği, benim şikâyet ettiğim şeyin bu anlaşmada seyircinin fazlasıyla şımarık hale dönüştüğünü, bu talebini yerine getirmek için de sinemanın kıvranıp durduğunu görüyorum. Bu büyük festivallerde de böyle. Yani hani sinemayı sanat olarak gören insanların da dahil olduğu bir dejenerasyon var diye düşünüyorum. Bunun da nedeni; bu seyirci-filim ilişkisinin masumiyetini kaybetmiş olmasıyla ilgili gibi geliyor. $\mathrm{O}$ yüzden eğer böyle bir izlenim bırakmışsa benim filmim, yani sinemanın başlangıcındaki o safiyeti işaret etmişse çok mutlu olurum ben.

Kadriye Baran: Ben de bir şeyler söyleyeyim. Öncelikle hoş geldiniz. Burada sizi görmek çok güzel. Ben de filmi çok beğendim, özellikle görüntü yönetmenliği, o 1şık huzmeleri arasındaki o sahneler de müthişti ama ben umut da gördüm. Mesela o gemiden gelen seslerde bence evet kıyamet kopacak ama bu çok da kötü bir şey değil, güzel bir şeyler de var hani. Korkmayın anlamında o müzik sesleri, ben öyle algıladım. Artı mesela sudan gelen ve tekrar denize giden çocuğun son bakışı, hani bu bir döngü, yani hani bundan öleceğiz ama tekrar dirileceğiz. Tekrar bu hayat devam edecek, korkacak bir şey yok, ben gidiyorum gibi, ben orada öyle bir şey algıladım. Tabi, arkadaşlarımız hep değindiler de, genelde insanların bulundukları ortamdaki sorunlara çözüm bulmak yerine sürekli onu başka yerlerde araması, işte başka insanlara, olaylara atıfta bulunması ve bu adam gelir gelmez sırtında o işareti görür görmez onu mehdi olarak algılamaları ama o yine de filmde sanki mehdi olmasına da yönelik bir iki ipucu var gibi geldi bana bilmiyorum.

T.P: Hiç o lekeyi görmüyoruz mesela... 
K.B: Görmüyoruz. Mesela o kızın kafamda yara var bak, çok bariz falan diyor, hala duruyor kurşun diyor ama adam epey bir saçını kurcalıyor ama hiç bir şey yok diyor. Sanki orada ben şey gibi mi? Evet o yara geçti gibi bir alg1 mı yaratılmak istenmiş.

T.P: Öyle bir şey kurmak istemedim açıkçası orada. Bu kasabaya sonradan gelen kişinin sırtında bir leke olduğu söyleniyor. Biz görmüyoruz çünkü. Belki de şöyle bir şey de var, hikâyeyi buradan da kurabilirsiniz; belki de orada bir leke olmasını istiyorlar ve dolayısıyla o ister istemez hiç aklının ucundan geçmeyen bir kimliğe bürünüyor, o da hatta acaba mı diye soracağ bir yere gidiyor.

K.B: Otel sahibi de mesela o çocuğa diyor ki mesela süpürge yaparken; durduruyor makineyi o zaten sen olamazsın hiçbir işaret yok diyor, tam esnada makine çalışıyor. Fakat orada da olabilir yani ne diyorsun gibi adamın kafasındakini...

T.P: Sürekli acabayı havada tutan bir şekilde tasarladım. Dolayısıyla bunun da cevabını kimse tam olarak veremez doğru. Yani belki de mehdiydi, belki de değildi bilmiyoruz.

K.B: O da öyle sanki askıda kalmış gibiydi.

T.P: Ama bu tam da günümüzün şeyi, peygambere atfettiğimiz kimliklerin aslında peygamber olmadığını biliyoruz biz ama inananlar var. Dolayısıyla aslında filmin böyle bir okumaya da açık bir tarafı olduğunu düşünüyorum. Bugün yalnız bizim topraklar değil, genel olarak dünyanın gidişatıyla ilgili de birtakım işaretler taşıyor bence.

S.D: Benim sormak istediğim bir şey var. Fragmanda üzeri yanarak koşan bir adam vardı. Filmden çıkarıldı mı o daha sonra?

T.P: Yoo var. Siz orada uyudunuz...(gülüşmeler)

S.D: Emin değilim diyecektim o yüzden.

T.P: Hiç şey yapmam, ben de birçok filmde uyuyorum zaten...(gülüşmeler)

S.Ö: Kendi filminiz de mi? (gülüşmeler)

T.P: Kendi filmlerimde de uyuyorum (gülüşmeler)

S.D: Ben o sahneyi görmek istedim ama demek ki...

T.P: Size ben link atayım, sadece onun yerini

L.K: Ercan Kesal'ın oynamış olduğu ve deri ceketi ve tavrı nedeniyle benim biraz bu 80 darbesi ve sonrasına adreslenebileceğini düşündügüum karakterle ilgili olarak işte kızının evlendirilmesi, orada bir...

K.B: Ama orda düğün sahnesinden kimse yoktu, böyle sanki Balkan düğünü gibi de algilaniyordu.

T.P: İçeriden sesler geliyordu. 
K.B: İçerden bir sesler geliyor sanki bir bant kaydı mı acaba? İyi zamanı da yaşamak mı istiyorlar...

T.P: Oradaki şey işte düğün bitmiş, çalgıcılar da artık pasta yiyorlar falan, içeriden de bir takım sesler geliyor. Yani düğün sonrası gibi.

L.K: $\mathrm{Bu}$ işte gerçek ve gerçek olmayan arasındaki bağ gibi galiba. Yani tuhaf bir benzetme olarak algılayabilirsiniz ama hatırlarsanız Metin Erksan'ın Sevmek Zamanı'nda, kendi düğününden kaçmadan önce arkada işte o gölgeler halinde dans eden insanlar görülür. Bende bu izlenimi yarattı. Kamera çok dışarıda kaldı ve bir haber geliyor işte iş arkadaşından ve birlikte gitmeleri gerekiyor. Sanki bu kendi ailemi bağımsız tutuyorum ya da böyle bir özel alanı bağımsız tutuyorum ama ne olacak şimdi sorusunu tamamlayamamış ve 80'e göndermede bulunan bir karakter olarak nitelendirdim çünkü o yıkılmış evde de sorduğu şey: "şimdi ne olacak?" ne olacak? Yani anlamı ya da anlamsız günlük dilde karşılığını bulabilse rahatlayacak.

T.P: Acıklı bir şekilde o bir anlam vermeye çalışıyor çünkü oradaki sizin de belirttiğiniz gibi muhtemelen bir polis ve karanlık. Bu ülkenin tarihini biraz bilenler için anlamlandırması zor olmayacak bir karakter ama bütün çabası ne olacağını öğrenmek. Aynı zamanda sıradan bir karakter, kötü de aslında. Yani öldürdüğünü, insanları öldürdüğünü görmüyoruz ama işitiyoruz. Matbaada, kağıthanede.. Bu kötünün dahi bile anlam veremediği bir zaman ve onun da derdi, kızını evlendirecek, kıyamet kopacaksa bunun ne anlamı var. Bari masrafa girmeyim der gibi yani. Bu kadar aptalca, bu kadar süfli ve bu kadar manasız bir şekilde çırpınıp duran bir grup insan. Yani bizatihi bugün bizim bulunduğumuz hali işaret ediyor diye düşünüyorum. Yani bu bir, korkanlar bile kaçmak için normal bir çaba gösteremiyor. Bir çaresizlik hali ve manasızlık ve çaresizlik hali. Dolayısıyla bunun neye tekabül ettiği aşağı yukarı bu.

L.K: Rıza Akın çok sevdiğim bir oyuncu. Burada sanki arafta biraz daha net gibi. Gidebiliyor ve geri dönebiliyor ve sembolik düzeni tamamıla yıkıp bunu dile de dökemiyor çünkü yaşadıkları muhtemelen çok ağır görmüş oldukları ama burada da o anlamsızlığın yaratmış olduğu bir hava var.

T.P: O kullanılan birisi. Bürokrasinin kirli işlerde kullandığı bir adam ve o her tarafta dolaşabilir.

L.K: O yüzden mi fare benzetmesi ve fare zehriyle ilişkilendirilmesi?

T.P: Bu filmde hep kadınlar öldürülüyor fakat onu öldüren kadın. Dolayısıyla onun cezasını da bir kadının vermesini istedim doğrusu. (gülüşmeler)

K.B: Ben o küçük kızın denizkızı olmasını çok anlayamadım açıkçası.

T.P: Şimdi size bir şey itiraf edeyim, madem bu kadar şey yaptını. Benim yine çocukluğumdan bir obsesyonum var. Ben Trabzonluyum, Trabzon'da fuar kurulurdu yaz günü çocukluğumda küçücük bir alanda. Onun bir lunaparkı olurdu, lunapark işte bu kadar bir alandı. Orada her sene bir denizkızı gelirdi. Denizkızı dediğim bir akvaryum, akvaryumun içinde bir çocuk, çocuk böyle yatmış size bakardı, muhtemelen önünde bir cam var, arada bir 
su olan bir cam daha var. Herkes bilirdi bunun sahte olduğunu ama gider bakardık böyle. $\mathrm{O}$ resmi hiç unutamadım ben. Bir bu beni çok etkilemiş olduğu için çocukluğumdan gelen birisi, ikincisi denizkızına atfedilen masumiyetle ilgili bir şey yani oradaki filmin en masum karakteri hem bir çocuk hem de denizden gelmiş bir balık. Yani o ikisi böyle bir safiyet işaretidir diye.

E.G: Benim de $80^{\prime}$ le ilgili yani her ne kadar deneyimlemesek de post bellek inşamızda belki o kadar derin yer etmiş ki, ben de aynı okumayı şimdiden yapabiliyorum aslında. Bir kaç yerde daha ben o duyumu çıkardım, örneğin matbaacının öldürülmesi.

T.P: Doğru.

E.G: Filimde gemiden gelen müzik sesi dışında bir müzik sesiyle karşılaşmadığımız gibi bandocuların sadece bir devlet yöneticisi oraya gelecekse bir müzik duyabileceğimiz, o da gelmedikçe bandocuların da hiçbir şekilde hani müziğe dair, onlardan bir tını duyamıyoruz. Yani sanki müziğin de, matbaanın da bir bürokrasi tarafından sürekli kontrol altında tutuluşu, dönemsiz bir şekilde verilmiş.

T.P: Bütün kasaba tutuluyor aslında.

E.G: Yani bir dönem de olabilir.

T.P: Yani bütün kasaba, görünmez bir baskı var bu çok belli ki oranın yöneticilerinin kurduğu bir baskı ve bu işte matbaa basmak, adam öldürmek, kitap yakmak falan filan vaka-i adliye şeklinde herkesin çok etkilenmediği bir şekilde oluyor. Bunun nereyi gösterdiği bence çok belirgin. Yani, biraz katmanlı bir hikâye bu. Yani aynı andan bir kaç şey anlattığım için bunların her birini tek tek ifade etmek güç.

K.B: Bir de ben hani şey derler ya, karamsar bir roman okuduğunuzda ya da film izlediğinizde siz de o filmin içerisine girince sıkılırsınız, bir an önce bitsin, onlarla birlikte aynı stresi yaşarsın ya, ama ben sizin filmlerinizi izlerken onu çok yaşayamadım açıkçası sadece filme odaklandım, sanki böyle şey, filmden sonra daha çok izleyicinin düşünmesine yönelik yani filmin içine almayan, dışarıdan bir gözle bakan ama filmden sonra da mesela bu Yol Kenarı filmini izledikten sonra ben epey böyle kavramları inceleme araştırma ihtiyacı hissettim ama o mesela kıyamet filmi, sıkılmadım yani o strese girmedim. Dışarıdan bir gözle gördüğümü hissettim, ama sadece bir sahnede o belediye başkanı gibi olan adam telefonla konuşurken ki o kamera hareketinde inanılmaz böyle bir sanki filmin içerisine aldı beni o, çok enteresan. Mesela onu sevdim yani, başındaki sahne.

T.P: Şöyle kurmaya çalışıyorum açıkçası. Yani filmle seyircinin arasında bir mesafenin olması gerektiğini düşünüyorum. Yani soğuk bir alan. Onun filmle kurulan ilişki sonucunda izleyiciyle filmin yaklaşması talebim var. Bu da ancak demin söylediğim gibi seyircinin algısı, sezgisiyle kat edilebilir bir mesafe. Aksi takdirde zaten film burada başliyorsa, ana akım sinema burada başlatıyor zaten, sizin hiç şansınız yok. Kaçamazsınız bu filmin size anlatmaya çalıştı̆̆ 1 şeyden kaçamazsınız. Ben işte seyirci ile araya bir mesafe koyarak mesafenin başlıklı olarak yaklaşmasını yapmaya çabalıyorum. Bu da gerçekten size soru sorduruyorsa ve siz de bu soruları cevaplamak için bir çabanız oluyorsa, isteğiniz oluyorsa daha doğrusu, o zaman 
içine giriyorsunuz. O zaman evet bu, zaten anlamıyorum, sinemanın ya da edebiyatın bu şekilde adlandırılması. Mesela, müzik marketlerde de var ya easily slow diye yazıyor, yani o ne demek, orada dinlediğin zaman rahatliyorsunuz size hoş melodiler çalıyor, çok güzel evet ama müzik bundan ibaret değil ki. Ama bu alan o kadar genişledi ki easiliy slow denen, bütün marketi kaplıyor şu anda. Dolayısıyla siz yattığınız yerden sizi uyutacak melodiler, şahane evet, ben de çok seviyorum ama müzik bu değil, sanat bu değil. Bence sanat tüketicisiyle karşılıklı dans etmeyle bir haz nesnesi haline gelebilir.

K.B: Bir de bir röportajınızda şey demişsiniz; "huzuru bulabilmek için dibe batılması gerekiyor" ama filmlerinizdeki karakterler hepsi dibe batmış ama bir türlü huzuru bulamıyorlar ya, huzuru bulacak bir film olacak mı acaba? (Gülüşmeler)

T.P: Olmayacak galiba... (Gülüşmeler)

S.Ö: Umutsuzluğun kendisi düşünceye baskı yaptığı için, yani siz umutsuz kaldığınız da düşünmek zorundasınız. Dolayısıyla o negativity dediğimiz şeye de biraz önem vermek gerekiyor. Mesela Sokrates'in felsefesinde uçurumun kenarına getirip sizi bırakma vardır. Bu aporia durumu. Aporia durumunda ancak, uçurumun kenarında düşünmeye başlıyorsunuz. Bazıları hep umut, umut, umut diyor ama umut nerede ne kadar olmalı, bence çok önemli. Filmde onun dozajını vermek önemli. Tamamen umut verdiğinizde de film kendi içerisinde her şeyi çözüyor zaten. Filmden sonra hiçbir şey düşünmek zorunda değilsiniz ama mutsuzluk durumunda biz sürekli düşünmek zorunda kalıyoruz. Filmden sonra da zaten sürekli düşünüyoruz. Bu ne demek, şu ne demek? Bunun üzerine kavga ediyoruz, imajlarla savaşıyoruz. Mesela ben sonradan düşündüm, bu elektrik süpürgesi var ya, mermi şeklinde ve idea, üzerine de idea konmuş ve sonra yerleri süpürüyor. Şimdi yani demek ki düşünce o kadar ayaklar altında ki, ya savaşla meseleleri çözüyorsunuz, ya da çöpler düzeyinde, kanaatler düzeyinde bir düşünce. Düşünce ayaklar altında. Yani benim düşündüğüm hissettiğim şeylerden birisi buydu, bunu yönetmen belki böyle düşünmek zorunda değil ama sonuçta filmdeki imajlar size bunu düşündürüyor. O karakterler arasındaki yabancılaşma, iletişimsizlik. Acaba gerçekten uzayda mı gerçekleşiyor bunlar, şu anda biz bunları yaşamıyor muyuz? Yani medyaya baktığımızda, kendi aramızdaki konuşmalara baktığımızda bunlar da biraz bu hatta girmedi mi? Yani bu aslında gerçeküstü bir sinema mı? Yani başka bir yerde mi gerçekleşiyor? İçinde yaşadığımız ilişkiler böyle değil mi? Dolayısıyla o anlamda bize düşündürüyor. Ama özdeşleşme, hayır. Özdeşleşmeye imkân vermiyor, zaten özdeşleşme gerçekleşse, klasik bir ana damar, konvansiyonel sinema izlemiş oluruz. O da çok anlamlı değil. Abbas Kiarostami kendisi ile yapılan bir röportajda öyle diyor; "benim en çok seyrettiğim film, sıkıldığım filmdir. Sıkıldığım filmler sayesinde geceleri o film rüyalarıma girmekte ve onlarla buluşmaktayım" diyor. Dolayısıyla sıkıldı̆̆ımız filmler, bazen iyi filmler olabilir. Hani bazen diyorlar ya "biz bu filmden sıkıldık" ama geriye doğru baktığımızda bizi sıkan filmleri biz hatırlıyoruz. Fırat'ın deyimiyle bizi çarpan imajlar ancak orada bulunuyor. Yani meselenin bir de bu yönü var.

K.B: Bir de filmlerde genelde aynı oyuncularla çalışıyorsunuz, onun nedeni ne?

T.P: Benim öyle bir demirbaş kadrom var. 
K.B: Ercan Kesal mesela. İyi yönetmenlerin kendisi mi ona gidiyor, yönetmen mi ona gidiyor?

T.P: Yönetmenler ona gidiyor tabi ki. Ercan şimdi filme başlayacak Temmuz'un ortasında, dolayısıyla artık ona gidecekler yani. Giden çok var. Ben de auditionlarına yardımcı oluyorum. Yani o başka bi..ben mesela hiç audition yapmiyorum. Söylediğinizle de alakalı. Demin anlattığım şeyden dolayı. Yani audition yaparken, oyuncuyu çağırmak ve ona al şunu oyna demek bence çalışan bir sistem değil. Yapmadım mı? İlk başta yaptım ve hiç bir faydasının olmadığını gördükten sonra bir kere yaptım ve vaz geçtim. Benim için önemli olan, demin anlattığım şeyden de dolayı, işin samimiyetini, işin hakikatini kurmakla ilgili olarak, oyuncunun da numara yapmayacağını anlamam lazım. Sanki oyunculuk sadece iyi numara yapmakmış gibi geliyor ama değil. Onun da trikleri var, onun da numaraları var. Konuşarak ben oyuncuyla bunu anlayabiliyorum, mimiklerini falan. Dolayisiyla bu kadronun dışındakileri tanıyorum biliyorum yani onların oyunculuk kapasitelerini, samimiyetlerini, her şeylerini bildiğim için o hem beni rahatlatan, hem onları rahatlatan bir şey. Yani mesela bu filmi de yalnız, tabi bu kalabalık bir kadro, başka oyuncular da vardı, ilk defa çalıştığım oyuncular. Ben bir de oyuncunun biraz tedirgin olmasını istiyorum. O yüzden bazı oyunculara senaryoyu vermedim. Sadece onların olduğu kısmı verdim. Yani ne olduğunu tam olarak anlamadan, onun tedirginliği ile oynasınlar istedim. Arka planda çalışan, yani her zaman olmayabilir ama iyi kontrol edilebilir. Bu filmde bazı oyuncular, ne oynadıklarını bilmeden oynadılar. O size yönetmen olarak, işte orada esas o hamuru nasıl yoğuracaksınız, orada yoğurmanız lazım.

K.B: Ben O Değilim filminde mesela halktan insanlar da var mıydı? Mesela otel sahnesinde falan?

T.P: Vard1.

K.B: Oyuncular çok iyi oynamışlar, yönetmenin gücü...

T.P: Bu bir risk tabi ama ben en büyük riski en başında aldım. Mesela, Rıza filmindeki Rıza Beyi ben bir kahvede gördüm Adana'da. Oradan aldım. Hiç oynamamıştı hayatında bir sinema filminde.

F.O: Filimdeki sokaktaki kalabalık da daha grotesk tiplerdi.

T.P: Aynen

F.O: Brueghel'in bir tablosundan çıkmış gibi ya da Pasolini'nin filmlerinde arkadaki karakterler gibi.

T.P: O Trabzon'un lokal...(gülüşmeler). Trabzon'a giderseniz sokaklar öyle... Onlar evet, Trabzon'dan aldım.

L.K: Sinemada çift-gezer dediğimiz şey genellikle işte diğer filmlerinizde de var, hep başka bir karakterin yerine geçme ya da o karakterin kimliğine bürünmeyle ilgili. Bu filmde biraz kırıldı $\mathrm{m}$ bu ya da işte tırnak içindeki "mesih" göndermesi, suyun içinde daha sonra yatakta gördüğ̈ümüz, herkesin “Bacağı var mı?” ya da “Bacağında leke var mı, yok mu?" diye baktığ1 
kız ve mesih sanılan karakter arasında, isimleri olmadığı için, sürekli benzetmeler üzerinden gidiyorum. Bu sefer o çift-gezerliği farklı bir anlamda mı kullandınız?

T.P: Şöyle kullandım, burada da bir kimliğin atfedildiği karakterler var ama bu o mudur değil midir onu bilemiyoruz. Dolayısıyla bu kimlik problematiği bence burada da var. Burada birinin yerine geçmek yerine, onu temsil ettiğini ısrarla iddia edenler, hayır olmadığını söyleyenler çerçevesinde oluyorlar. Ben bu birinin yerini almak, birey olmak şeyini çok seviyorum. Bir başka obsesyonum daha varmış...(gülüşmeler).

F.O: İkizini arayan vardı mesela.

T.P: Evet. Orda evet ikizini arayan var. Biraz bu yine eskatolojik edebiyatı bilenler için, onunda temsil ettiği bir şey var.

L.K: Bir de, eğer bir ismi olsaydı kadın karakterin ismi Leyla olacaktı galiba, Malihulya' daki gibi. Doğru mu okuyorum? Sürekli çünkü bir kadın gibi, Leyla'nın aranışı vardır o romanda. Burada da hep bir takip var. Hemşire takip ediliyor gittiği yere kadar, daha sonra işte "Ben uyuyacağım git artık" deniliyor. Sanırım oradaki tematiklik de romanlarla ilintili.

T.P: Evet romanın bir... Başka kitaplarımda da var bu kadın karakter, böyle gizemli ve takip edilen, aslında sonradan mesafe koyan, uzaklaştıran kadın... İsmi evet Leyla olabilir (gülüşmeler)

K.B: Elma ve göz, bu sahneyi ilk başta görüyoruz, sonra yine elma ve gözü hemşirenin evinde görüyoruz. Bu başta planladığınız bir şey miydi?

T.P: Filmin en başından beri atmosferle, mekânla ilgili böyle şeyler koymak istedim. Bu hikâyeyi burada seyredeceksiniz, bunları göreceksiniz gibisinden.

S.Ö: Evet, yorgun mekânlar, yorgun insanlar, karakterler, yorgun bir dünya... Ve nihayetinde SineFilozofi Dergisi'nin bir etkinliğinin de sonuna gelmiş bulunmaktayız. Sona mı geldik yoksa başlangıca mı? (gülüşmeler)

T.P: Başlangıç (gülüşmeler)

S.Ö: Tayfun Bey'in filminden esinlenerek söylersek, umarım bu tür yeni yapımlarla bizi meşgul etmeye devam eder, yeni sorular sorarız, hiç olmazsa sinema felsefesi dergimize yeni yeni malzemeler, yeni yeni konuşma konuları... Tayfun Bey, buraya geldiniz ve bize son derece değerli bilgilerinizi aktardınız, görüşlerinizi aktardınız. Güzel bir tartışma olduğunu düşünmekteyim. İlk defa belki yönetmenin dünyası ve seyircilerin dünyası böylesi bir sinema kritiğinde bir araya geldi. Belki de ilk defa size seyirciler burada bunu mu anlatmak istedin diye, size filmi anlattırmak zorunda kalmadilar.

T.P: Evet, bundan dolayı müteşekkirim.

S.Ö: Farklı bir seyirci kitlesi. Belki de gözlerimizi bu şekilde geliştirebilirsek, değiştirebilirsek, Türkiye'de yepyeni, pedagojik anlamda yeni bir sinema seyircisi de inşa edilebilir. Bu meseleler biraz daha çözülebilir. Ben bu her zaman söylüyorum ama bir tek örnek vereceğim. 1914 yılıydı zannedersem, biz bunu bir kitapta da okumuştuk hatta. Stravinski'nin "Bahar 
Resitali" bestesi. O gösterildiğinde izleyiciler yuhalıyor. Yani bu nasıl bir şey, sadece gürültü diyorlar. Dört yıl sonra, dört yıl içerisinde tartışmalar oluyor, müzik eseri üzerine yoğun yoğun yoğun alımlama çalışmaları. En sonunda varılan nokta Stravinski el üstünde taşınıyor. Yani çünkü öznenin kendisi dönüşüyor. Yani bizim aslında sormamız gereken soru; nesnede mi sorun var? Öznede mi sorun var?

T.P: Bununla ilgili çarpıcı bir örnek var. Meşhur Antonioni'nin L'avventura sı, 1960 yılında, Cannes' da yuhalanıp, yarıda kalıyor film. Ağlayarak kaçıyor Antonioni ve sonra oradaki diğer yarışmacılar, imza topluyorlar ve film bir daha gösteriliyor. Bir ödül de veriyorlar, yan bir ödül. Fakat seyircinin, bu acımasızlı̆̆ L'avventura gibi bence sinemanın şahikalarından bir filmin seyircinin algısındaki karşılığının, üstelik de Cannes' da böyle olması inanılacak bir şey değil ama bence işte sinema ancak böyle cesur hamlelerle bir yere gidebilir.

S.Ö: Demek ki böyle hamlelere ihtiyacımız var, sizin filminiz de cesur bir hamle.

T.P: Ben cesaret örneği olarak kendimi göstermek için söylemiyorum.

S.Ö: Umarım devamı gelir. Bir sonraki görüşmemizde tekrar bir araya geliriz, tartışırız. 